\title{
INFLUENCE OF ADDITIVES ON SPECTROSCOPIC CHARACTERISTICS OF THE CARMINIC ACID
}

\author{
Violeta Rakić ${ }^{\text {, Milena Miljković }}{ }^{2}$, Vojkan Miljković ${ }^{3}$ \& Nemanja Stančić ${ }^{4}$ \\ ${ }^{1}$ College of Agriculture and Food Technology, Ćirila i Metodija 1, 18400 Prokuplje, Serbia \\ phone: +38127/324-311, +381698702552, e-mail: violetachem@gmail.com \\ ${ }^{2}$ Department of Chemistry, Faculty of Science and Mathematics, University of Niš \\ Višegradska 33, 18000 Niš, Serbia, phone: +381 654292621, e-mail: milenabmv@gmail.com \\ ${ }^{3}$ Department of Pharmacy, Faculty of Medicine, University of Niš \\ Bulevar Dr Zoran Djindjić 81, 18000 Niš, Serbia \\ phone: +381 18 4238770, e-mail: vojkanmm_serbia@yahoo.com \\ ${ }^{4}$ Megatrend University of Belgrade, Faculty of Biofarming, Bačka topola, Serbia \\ phone: +381 69 2752761, e-mail: stancicn@gmail.com
}

\begin{abstract}
Foods must have attractive color, flavor and texture to be acceptable to consumers. Carminic acid (C.I. (1956) 75470; C.I. Natural Red 4; EEC No. E120) is a natural red dye extracted from cochineal, the desiccated bodies of female Dactylopius coccus Costa insects. Carminic acid produce pink shades in candy, confections, chewing gum, concentrated fruit juice, smoked fish, liqueurs and alcoholic cordials, soft drinks, yoghurt, ice cream, tomato ketchup, baked goods, dairy products, jams, jellies, eye shadow, and pill coatings. The impact of the presence of aspartame, citric acid and vitamin $C$ on the spectrophotometric parameters of carminic acid was investigated. These results enabled us to evaluate the possibility of using UV-Vis spectrophotometric method for easily identifying and quantifying carminic acid present in a wide variety of foodstuffs in the presence of additives. It was established that the investigated additives do not affect the position of absorbance maximum of the dye nor cause changes in its intensity. The value of molar absorptivity, $\varepsilon$, at $518 \mathrm{~nm}$ was $1265.68 \pm 49.90 \mathrm{dm} / \mathrm{mol} \cdot \mathrm{cm}$. The calculated value is necessary for the quantitative spectrophotometric determination of carminic acid food dye. The FT IR spectra of the dye was also recorded.
\end{abstract}

Keywords: food dyes, carminic acid, aspartame, citric acid, vitamin C, UV-Vis spectrophotometry.

\section{INTRODUCTION}

Foods must have attractive color, flavor and texture to be acceptable to consumers [1]. Color is one of the most important organoleptic attributes that directly affects consumers' acceptance and food selection [2]. However, despite the fact that natural food products have their own color intensity, storage conditions, manufacturing and processing practices/methods have a pronounced influence on their final coloration [2]. Thus, food colorants are mainly applied to offset and overcome those unpleasant characteristics, as also to homogenize the color of foodstuffs, through correction of colour variations and/or enhancement of the naturally occurring food colour, and even making available colourless products [2]. There are two general classes of added food colorants: synthetic colours and natural colours [1].

The growth in use of natural colours comes from increasing consumer pressure for 'natural' products in light of their distrust of the food industry, based on health scares related to additives in general, but especially related to hyperactivity and its perceived association to many azo dyes such as tartrazine [3]. Natural food colorants have been demanded and become increasingly popular among worldwide consumers; their safety, functional and

IRTIIE Vol. 6, No. 4, 2018 ISSN 1314-8788 (print), ISSN 1314-8796 (online), doi: 10.15547/artte.2018.04.008 


\section{ARTTIE $Y$}

Ipplied Resseirlohes in Technics, Technologies and Bductation

Journal of the Faculty of Technics and Technologies, Trakia University https://sites.google.com/a/trakia-uni.bg/artte/

biological potential, health effects, as well as the whole impact at short and long terms, still continues to be exploited and markedly benefits of their consumption have been stated [2]. In comparison to synthetic colorants with great perceptions of undesirable and harmful effects, natural ones tend to be perceived by consumers as safer [2].

Carminic acid (C.I. (1956) 75470; C.I. natural red 4; EEC No. E120) is a natural red dye extracted from several insect taxa: Kermes vermilio (Kermes), Porphyrophora polonica (Polish cochineal), Porphyrophora hamelii (Armenian cochineal), Dactylopius coccus (American cochineal or simply cochineal), and Kerria lacca (lac - often referred to by its old name: Laccifer lacca). The pigments, which are chemically classified as anthraquinones, are extracted from dried gravid insects using boiling water. The main pigment $(>95 \%)$ in cochineal is the C-glycoside, carminic acid (Figure 1,a), while lac contains several different pigments, predominantly laccaic acids $A, B$, and $C$ (Figure 1,b-d). Carminic acid has the ability to form chelates with metal ions (aluminium and calcium) termed carmines. Therefore, cochineal extracts or carminic acid may be treated with alum to produce the colourant. The use of this chemical causes the colouring and the precipitation of the animal matters. The quality of carmine is affected by the temperature and illumination during its preparation, sunlight being a prerequisite for the production of a brilliant hue. Several cases of strong allergy and asthma have been reported with this pigment. In the food industry, carmine is also referred to as cochineal, cochineal extract, crimson lake, and natural red 4 . Its colour in solution changes with $\mathrm{pH}$ since the phenolic groups are rather acidic. Thus, at low $\mathrm{pH}$ carminic acid is orange, changes to red at slightly acidic and neutral $\mathrm{pH}$, and finally turns violet in alkaline solution [4].<smiles>Cc1c(C(=O)O)c(O)cc2c1C(=O)c1c(O)c([C@H]3O[C@H](CO)[C@@H](O)[C@H](O)[C@H]3O)c(O)c(O)c1C2=O</smiles>

(a)<smiles>O=C1c2cc(O)c(C(=O)O)c(C(=O)O)c2C(=O)c2cc(-c3cc(CO)ccc3O)c(O)c(O)c21</smiles><smiles>CCOC(C)=O</smiles>

(b)<smiles>NC(=O)Cc1ccc(O)c(-c2cc3c(c(O)c2O)C(=O)c2cc(O)c(C(=O)O)c(C(=O)O)c2C3=O)c1</smiles>

Figure 1. Chemical structure of cochineal and lac pigments. (a) Carminic acid, (b) laccaic acid A, (c) laccaic acid B, and (d) laccaic acid C [4]

According to the EU legislation, commercial preparations of carmine should contain at least $2 \%$ carminic acid in extracts containing carminic acid and not less than $50 \%$ carminic acid

IRTIIE Vol. 6, No. 4, 2018 ISSN 1314-8788 (print), ISSN 1314-8796 (online), doi: 10.15547/artte.2018.04.008 
chelates. E120 can contain substantial amounts of aminocarminic derivates formed during carminic acid heating in the presence of ammonia. Aminocarminic acid maintains deep red colouring power at very low $\mathrm{pH}$, but is not approved as a food colourant. It is sold and illicitly used as an acid-stable carminic acid suitable for acidic food [4].

Carminic acid is neither toxic nor known to be carcinogenic [5]. This coloring agent is quite expensive when compared to other natural red ones, like anthocyanins, although it is considered technologically important due to its stability [6].

The major usage of carminic acid lies in the food, cosmetic and pharmaceutical industries [7]. Carminic acid produce pink shades in candy, confections, chewing gum, concentrated fruit juice (except orange), lobster paste, smoked fish, liqueurs and alcoholic cordials, soft drinks, yogurt, ice cream, tomato ketchup, baked goods, dairy products, jams, jellies, eye shadow, rouge and pill coatings $[6,8]$.

Carminic acid has been quantitatively determined by HPLC in foods [8]. UV-Vis spectrophotometric analysis has shown to be suitable for the identification of this dye in wool fibers [9].

In this paper the impact of the presence of aspartame, citric acid and vitamin $C$ on the changes in the positions of the absorbance maximum and change of its intensity in the visible range of carminic acid spectra was investigated. These results enabled us to evaluate the possibility of using UV-Vis spectrophotometric method for easily identifying and quantifying carminic acid present in a wide variety of foodstuffs in the presence of additives.

To the best of our knowledge, there are no literature data whether additives present in foods influence on the change of the position of dye absorbance maximum and its intensity upon UV-Vis spectrophotometric analysis, which can be used for the quantitative determination of food dyes.

\section{EXPERIMENTAL}

\subsection{Material}

The carminic acid, vitamin C (E300), citric acid (E330) and aspartame (E951) used as standards for the quantitative analysis were from Tovarna arom in etericnih olj (Celje, Slovenia).

\subsection{Method}

\subsubsection{Preparation of the standard solution of carminic acid}

A sample of carminic acid was used as a standard for quantitative analysis. The standard solution of carminic acid was prepared by the dissolution of dry, pure substance in the distilled water. By diluting the standard solution, a series of solutions with concentrations of $0.0200,0.0250,0.0300,0.0350$ and $0.0400 \mathrm{~g} / \mathrm{dm}^{3}$ were prepared. The absorption spectra of the series of solutions were recorded in the range 190-900 nm using a UV-Vis spectrophotometer (Perkin Elmer Lambda 15 UV/VIS, Waltham, Massachusetts, USA). It was found that at $518 \mathrm{~nm}$ carminic acid had a absorbance maximum. Accordingly, the molar absorptivity at $518 \mathrm{~nm}$ of color was determined.

The influence of vitamin $\mathrm{C}$ as an additive on the changes in the positions of the absorbance maximum and change of its intensity in the visible range of the carminic acid spectra $\left(\lambda_{\text {max-vis }}\right)$ was investigated. The series of solutions were made by the dissolution of dry, pure substance in the distilled water. The solutions had the constant concentration of carminic acid and different concentrations of vitamin $\mathrm{C}$. Solution containing only the carminic acid (the same concentration) without vitamin $C$ was used as the control solution. The prepared

IRTIIE Vol. 6, No. 4, 2018 ISSN 1314-8788 (print), ISSN 1314-8796 (online), doi: 10.15547/artte.2018.04.008 


\section{ARTTIE $Y$}

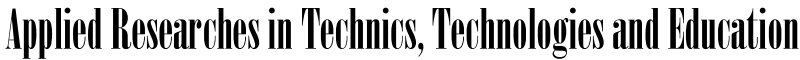

Journal of the Faculty of Technics and Technologies, Trakia University https://sites.google.com/a/trakia-uni.bg/artte/

solutions had the following concentrations: $0.0350 \mathrm{~g} / \mathrm{dm}^{3}$ dye and $0.0075 \mathrm{~g} / \mathrm{dm}^{3}$ vitamin C; $0.0350 \mathrm{~g} / \mathrm{dm}^{3}$ dye and $0.0150 \mathrm{~g} / \mathrm{dm}^{3}$ vitamin $C$ and $0.0350 \mathrm{~g} / \mathrm{dm}^{3}$ dye and $0.0225 \mathrm{~g} / \mathrm{dm}^{3}$ vitamin C. The control solution contained $0.0350 \mathrm{~g} / \mathrm{dm}^{3}$ dye without vitamin C. The absorption spectra of prepared solutions were recorded $(190-900 \mathrm{~nm})$ and absorbance at $\lambda=518 \mathrm{~nm}$ were measured (immediately after solutions preparations) using a UV-Vis spectrophotometer (Perkin Elmer Lambda 15 UV/VIS, Waltham, Massachusetts, USA).

The influence of citric acid, as an additive on the changes in the positions of the absorbance maximum and change of its intensity in the visible range of the carminic acid spectra $\left(\lambda_{\text {max-vis }}\right)$ was also investigated. The series of solutions were made by the dissolution of dry, pure substance in the distilled water. The solutions had the constant concentration of carminic acid and different concentrations of citric acid. Solution containing only the carminic acid (the same concentration) without citric acid was used as the control solution. The prepared solutions had the following concentrations: $0.0350 \mathrm{~g} / \mathrm{dm}^{3}$ dye and $0.0313 \mathrm{~g} / \mathrm{dm}^{3}$ citric acid; $0.0350 \mathrm{~g} / \mathrm{dm}^{3}$ dye and $0.0626 \mathrm{~g} / \mathrm{dm}^{3}$ citric acid and $0.0350 \mathrm{~g} / \mathrm{dm}^{3}$ dye and $0.0939 \mathrm{~g} / \mathrm{dm}^{3}$ citric acid. The control solution contained $0.0350 \mathrm{~g} / \mathrm{dm}^{3}$ dye without citric acid. The absorption spectra of prepared solutions were recorded $(190-900 \mathrm{~nm})$ and absorbance at $\lambda=518 \mathrm{~nm}$ were measured (immediately after solutions preparations) using a UV-Vis spectrophotometer (Perkin Elmer Lambda 15 UV/VIS, Waltham, Massachusetts, USA).

The influence of aspartame, as an additive on the changes in the positions of the absorbance maximum and change of its intensity in the visible range of the carminic acid spectra $\left(\lambda_{\text {max-vis }}\right)$ was also investigated. The series of solutions were made. The solutions had the constant concentration of carminic acid and different concentrations of aspartame. Solution containing only the carminic acid (the same concentration) without aspartame was used as the control solution. The prepared solutions had the following concentrations: $0.0350 \mathrm{~g} / \mathrm{dm}^{3}$ dye and $0.0304 \mathrm{~g} / \mathrm{dm}^{3}$ aspartame; $0.0350 \mathrm{~g} / \mathrm{dm}^{3}$ dye and $0.0609 \mathrm{~g} / \mathrm{dm}^{3}$ aspartame and $0.0350 \mathrm{~g} / \mathrm{dm}^{3}$ dye and $0.0913 \mathrm{~g} / \mathrm{dm}^{3}$ aspartame. The control solution contained $0.0350 \mathrm{~g} / \mathrm{dm}^{3}$ dye without aspartame. The absorption spectra of prepared solutions were recorded (190-900 nm) and absorbance at $\lambda=518 \mathrm{~nm}$ were measured (immediately after solutions preparations) using a UV-visible spectrophotometer (Perkin Elmer Lambda 15 UV/VIS, Waltham, Massachusetts, USA).

\subsubsection{Preparation of the standard solution of vitamin C}

The vitamin $\mathrm{C}$ was dissolved in distilled water to $1.5002 \mathrm{~g} / \mathrm{dm}^{3}$.

\subsubsection{Preparation of the standard solution of citric acid}

The citric acid was dissolved in distilled water to $6.2602 \mathrm{~g} / \mathrm{dm}^{3}$.

\subsubsection{Preparation of the standard solution of aspartame}

The aspartame was dissolved in distilled water to $6.0863 \mathrm{~g} / \mathrm{dm}^{3}$.

\section{RESULTS}

Recorded absorption spectra of carminic acid shows that absorbance maximum of the dye occurs at $518 \mathrm{~nm}$, which is in accordance to literature spectroscopic data. The average molar absorptivity of carminic acid, $\varepsilon$, at $518 \mathrm{~nm}$ was $1265.68 \pm 49.90 \mathrm{dm}^{3} / \mathrm{mol} \cdot \mathrm{cm}$ (Table 1). This value of molar absorptivity can be later used to quantify the unknown dye concentration in the analyzed food samples. 
Absorbencies of series of solutions with the constant concentration of carminic acid and different concentrations of vitamin $\mathrm{C}$, citric acid and aspartame, respectively as well as control solution which contains only carminic acid without additives were measured on 518 $\mathrm{nm}$ and represented in Table 2, Table 3, and Table 4, respectively.

Table 1. Molar absorptivities of carminic acid and coresponding statistical parameters: average value $\left(\varepsilon_{\text {average }}\right)$, median $\left(\varepsilon_{\text {median }}\right)$, range of variation $\left(\varepsilon_{R}\right)$, mean deviation $\left(\varepsilon_{D}\right)$ and standard deviation $\left(\varepsilon_{\mathrm{SD}}\right)$

\begin{tabular}{|c|c|c|c|c|c|c|}
\hline \multicolumn{7}{|l|}{ Carminic acid } \\
\hline No & $\begin{array}{l}V_{\text {dye }} \\
{\left[\mathrm{cm}^{3}\right]}\end{array}$ & \multicolumn{2}{|c|}{ A } & $\begin{array}{c}\mathrm{C} \\
{\left[\mathrm{g} / \mathrm{dm}^{3}\right]}\end{array}$ & $\begin{array}{c}\mathrm{C} \cdot 10^{-5} \\
{\left[\mathrm{~mol} / \mathrm{dm}^{3}\right]}\end{array}$ & $\begin{array}{c}\varepsilon \\
{\left[\mathrm{dm}^{3} / \mathrm{mol} \cdot \mathrm{cm}\right]}\end{array}$ \\
\hline 1 & 19.40 & \multicolumn{2}{|c|}{0.492} & 0.020 & 4.06 & 1211.28 \\
\hline 2 & 24.20 & \multicolumn{2}{|c|}{0.645} & 0.025 & 5.08 & 1270.37 \\
\hline 3 & 29.10 & \multicolumn{2}{|c|}{0.785} & 0.030 & 6.09 & 1288.42 \\
\hline 4 & 34.00 & \multicolumn{2}{|c|}{0.870} & 0.035 & 7.11 & 1223.94 \\
\hline 5 & 38.90 & \multicolumn{2}{|c|}{1.084} & 0.040 & 8.12 & 1334.38 \\
\hline \multicolumn{7}{|c|}{ Statistical parameters } \\
\hline Dye & $\varepsilon_{\text {average }}$ & $\varepsilon_{\text {median }}$ & $\varepsilon_{R}$ & $\varepsilon_{D}$ & $\varepsilon_{S D}$ & $\varepsilon_{D}$ \\
\hline Carminic acid & \multicolumn{2}{|c|}{$\left[\mathrm{dm}^{3} / \mathrm{mol} \cdot \mathrm{cm}\right]$} & \multirow[b]{2}{*}{123.10} & \multirow[b]{2}{*}{38.45} & & \\
\hline$\lambda=518 \mathrm{~nm}$ & 1265.68 & 1270.37 & & & 49.90 & $\begin{array}{c}1265.68 \pm 49 \\
90\end{array}$ \\
\hline
\end{tabular}

From Table 2 it can be concluded that vitamin $\mathrm{C}$ as an additive neither affects the change of intensity of absorbance maximum of carminic acid, nor the change of its position.

Table 2. Absorbances of the series of solutions containing constant concentration of carminic acid and different concentrations of vitamin C, as well as control solution which contains only carminic acid without vitamin $\mathrm{C}$

\begin{tabular}{|l|c|c|c|c|c|c|}
\hline \multicolumn{6}{|c|}{ Carminic acid and vitamin C } \\
\hline No. & $\begin{array}{c}\mathrm{V}_{\text {dye }} \\
{\left[\mathrm{cm}^{3}\right]}\end{array}$ & $\begin{array}{c}\mathrm{C}_{\text {dye }} \\
{\left[\mathrm{g} / \mathrm{dm}^{3}\right]}\end{array}$ & $\begin{array}{c}\mathrm{V}_{\text {vitamin } C} \\
{\left[\mathrm{~cm}^{3}\right]}\end{array}$ & $\begin{array}{c}\mathrm{C}_{\text {vitamin C }} \cdot 10^{-} \\
{\left[\mathrm{g} / \mathrm{dm}^{3}\right]}\end{array}$ & $\begin{array}{c}\mathrm{C}_{\text {vitamin C }} \cdot 10^{-4} \\
{\left[\mathrm{~mol} / \mathrm{dm}^{3}\right]}\end{array}$ & $\mathrm{A}$ \\
\hline 1 & 34.00 & 0.035 & 5.00 & 0.75 & 0.43 & 0.882 \\
\hline 2 & 34.00 & 0.035 & 10.00 & 1.50 & 0.85 & 0.870 \\
\hline 3 & 34.00 & 0.035 & 15.00 & 2.25 & 1.28 & 0.874 \\
\hline 4 & 34.00 & 0.035 & 0.00 & 0.00 & 0.00 & 0.880 \\
\hline
\end{tabular}

Measurements of series of solutions containing the constant concentration of carminic acid and different concentrations of citric acid, as well as control solution containing only dye the same concentration without citric acid on $518 \mathrm{~nm}$ show that absorbances of these solutions are almost equal (Table 3).

Table 3. Absorbances of the series of solutions containing constant concentration of carminic acid and different concentrations of citric acid, as well as control solution which contains only carminic acid without citric acid

\begin{tabular}{|l|c|c|c|c|c|c|}
\hline \multicolumn{6}{|l|}{ Carminic acid and and citric acid } \\
\hline No. & $\begin{array}{c}\mathrm{V}_{\text {dye }} \\
{\left[\mathrm{cm}^{3}\right]}\end{array}$ & $\begin{array}{c}\mathrm{C}_{\text {dye }} \\
{\left[\mathrm{g} / \mathrm{dm}^{3}\right]}\end{array}$ & $\begin{array}{c}\mathrm{V}_{\text {citric acid }} \\
{\left[\mathrm{cm}^{3}\right]}\end{array}$ & $\begin{array}{c}\mathrm{C}_{\text {citric acid }} \cdot 10^{-2} \\
{\left[\mathrm{~g} / \mathrm{dm}^{3}\right]}\end{array}$ & $\begin{array}{c}\mathrm{C}_{\text {citric acid }} \cdot 10^{-4} \\
{\left[\mathrm{~mol}^{3} / \mathrm{dm}^{3}\right]}\end{array}$ & $\mathrm{A}$ \\
\hline 1 & 34.00 & 0.035 & 5.00 & 3.13 & 1.63 & 0.857 \\
\hline 2 & 34.00 & 0.035 & 10.00 & 6.26 & 3.26 & 0.842 \\
\hline 3 & 34.00 & 0.035 & 15.00 & 9.39 & 4.86 & 0.842 \\
\hline 4 & 34.00 & 0.035 & 0.00 & 0.00 & 0.00 & 0.844 \\
\hline
\end{tabular}

IRTIIE Vol. 6, No. 4, 2018 ISSN 1314-8788 (print), ISSN 1314-8796 (online), doi: 10.15547/artte.2018.04.008 


\section{IRTITE}

Measurements of series of solutions containing the constant concentration of carminic acid and different concentrations of aspartame on wavelength $518 \mathrm{~nm}$ revealed that absorbances of these solutions are almost equal (Table 4).

Table 4. Absorbances of the series of solutions containing constant concentration of carminic acid and different concentrations of aspartame, as well as control solution which contains only carminic acid without aspartame

\begin{tabular}{|l|c|c|c|c|c|c|}
\hline \multicolumn{2}{|c|}{ Carminic acid and aspartame } \\
\hline No. & $\begin{array}{c}\mathrm{V}_{\text {dye }} \\
{\left[\mathrm{cm}^{3}\right]}\end{array}$ & $\begin{array}{c}\mathrm{C}_{\text {dye }} \\
{\left[\mathrm{g} / \mathrm{dm}^{3}\right]}\end{array}$ & \begin{tabular}{c}
$\mathrm{V}_{\text {aspartame }}\left[\mathrm{cm}^{3}\right]$ \\
\hline 1
\end{tabular} & $\begin{array}{c}\mathrm{C}_{\text {aspartame }} \cdot 10^{2} \\
{\left[\mathrm{gg}^{3} / \mathrm{dm}^{3}\right]}\end{array}$ & $\begin{array}{c}\mathrm{C}_{\text {aspartame }} \cdot 10^{-4} \\
{\left[\mathrm{~mol}^{-4} \mathrm{dm}^{3}\right]}\end{array}$ & $\mathrm{A}$ \\
\hline 2 & 34.00 & 0.035 & 5.00 & 3.04 & 1.03 & 0.882 \\
\hline 3 & 34.00 & 0.035 & 10.00 & 6.09 & 2.07 & 0.880 \\
\hline 4 & 34.00 & 0.035 & 15.00 & 9.13 & 3.10 & 0.874 \\
\hline
\end{tabular}

FT IR spectra of the carminic acid is shown at Figure 2.

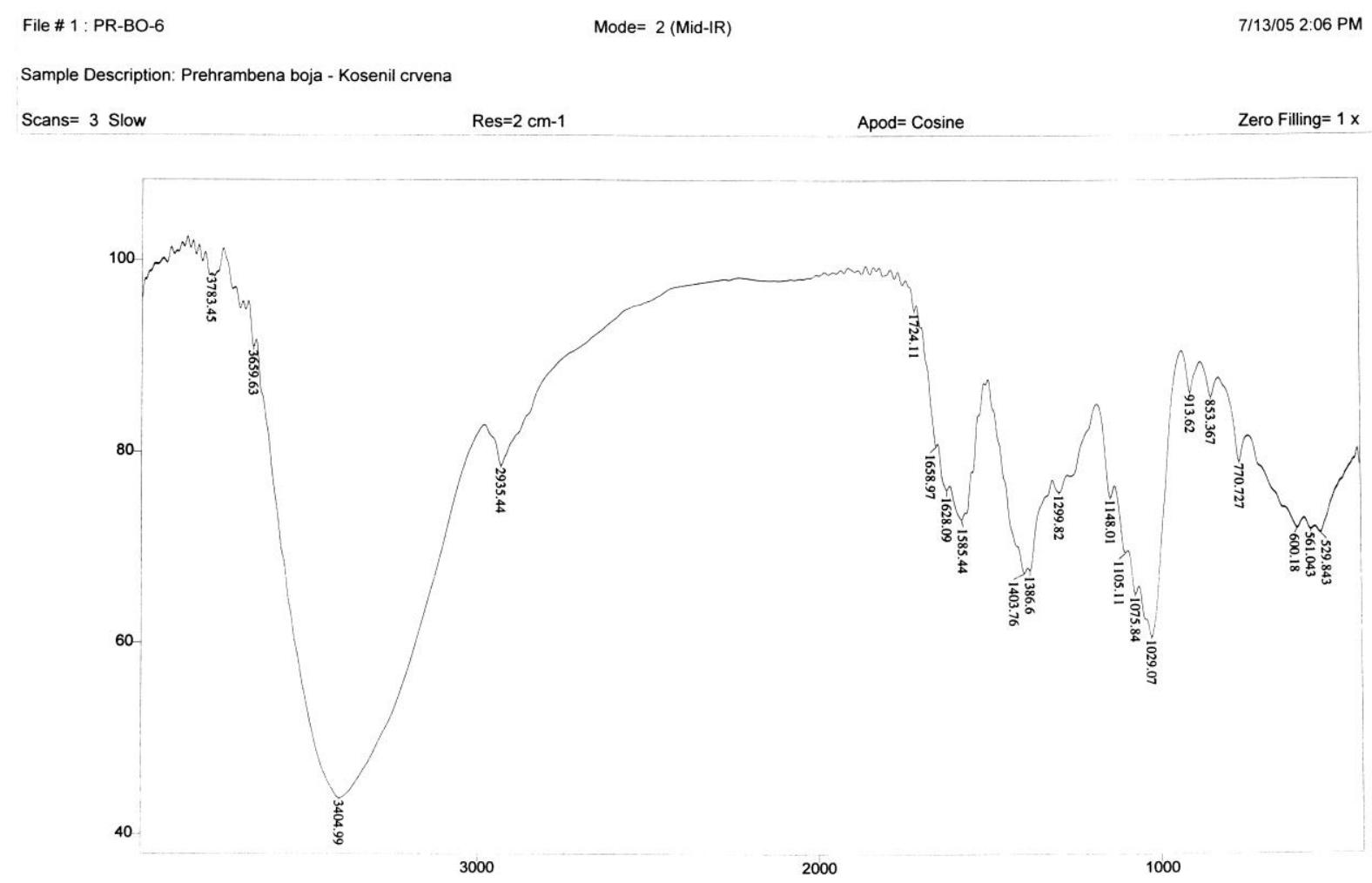

Transmittance / Wavenumber $(\mathrm{cm}-1)$

Figure 2. FT IR spectra of the carminic acid

Recorded FT IR spectra can be used for qualitative determination of the presence of carminic acid in different food samples.

IRTIIE Vol. 6, No. 4, 2018 ISSN 1314-8788 (print), ISSN 1314-8796 (online), doi: 10.15547/artte.2018.04.008 


\section{ARTTE $Y$}

Ipplied Researleches in Technics, Technologies and Educiation

Journal of the Faculty of Technics and Technologies, Trakia University https://sites.google.com/a/trakia-uni.bg/artte/

\section{CONCLUSIONS}

The use of additives (vitamin C, citric acid and aspartame) does not cause a change in the positions of the absorbance maximum and change of its intensity in the visible range of the carminic acid spectra. Therefore, it can be concluded that it is possible to quantify the carminic acid by UV-Vis spectrophotometric methods in the presence of these additives. The proposed method is fast, precise and economical.

\section{REFERENCES}

[1] F. J. Francis, A new group of food colorants, Trends Food Sci. Technol. 3 (1992) 27-30. doi:10.1016/0924-2244(92)90112-A.

[2] N. Martins, C. L. Roriz, P. Morales, L. Barros, I. C. F. R. Ferreira, Food colorants: Challenges, opportunities and current desires of agro-industries to ensure consumer expectations and regulatory practices, Trends Food Sci. Technol. 52 (2016) 1-15. doi:10.1016/j.tifs.2016.03.009.

[3] A. Downham, P. Collins, Colouring our foods in the last and next millennium, Int. J. Food Sci. Technol. 35 (2000) 5-22. doi:10.1046/j.1365-2621.2000.00373.x.

[4] K. Solymosi, N. Latruffe, A. Morant-Manceau, B. Schoefs, Food colour additives of natural origin, in: M.J. Scotter (Ed.), Colour Addit. Foods Beverages, Elsevier Ltd., 2015: pp. 4-34. doi:10.1016/B978-1-78242-011-8.00001-5.

[5] N. S. Bibi, L. Galvis, M. Grasselli, M. Fernández-Lahore, Synthesis and sorption performance of highly specific imprinted particles for the direct recovery of carminic acid, Process Biochem. 47 (2012) 1327-1334. doi:10.1016/j.procbio.2012.04.030.

[6] M. Carocho, P. Morales, I. C. F. R. Ferreira, Natural food additives: Quo vadis?, Trends Food Sci. Technol. 45 (2015) 284-295. doi:10.1016/j.tifs.2015.06.007.

[7] R. B. Cabrera, H. M. Fernandez-Lahore, Primary recovery of acid food colorant, Int. J. Food Sci. Technol. 42 (2007) 1315-1326. doi:10.1111/j.1365-2621.2006.01327.x.

[8] F. E. Lancaster, J. F. Lawrence, High-performance liquid chromatographic separation of carminic acid, alpha- and beta-bixin, and alpha- and beta-norbixin, and the determination of carminic acid in foods., J. Chromatogr. A. 732 (1996) 394-398. doi:10.1016/00219673(95)01332-6.

[9] M. S. Maier, S. D. Parera, A.M. Seldes, Matrix-assisted laser desorption and electrospray ionization mass spectrometry of carminic acid isolated from cochineal, Int. J. Mass Spectrom. 232 (2004) 225-229. doi:10.1016/j.jjms.2003.12.008. 